\title{
Rethinking Cultural Appropriation in YA Literature Through Sámi and Arctic Pedagogies
}

\author{
Lena Manderstedt $^{1}$ (D) Annbritt Palo ${ }^{1}$ D $\cdot$ Lydia Kokkola $^{1}$ (D)
}

Published online: 13 March 2020

(c) The Author(s) 2020

\begin{abstract}
This article highlights cultural appropriation in the literary representation of the Sámi (the indigenous people of the European Arctic) in two Swedish YA series: the Soppero quartet by the Sámi author Ann-Helén Laestadius, and the Idijärvi trilogy by Charlotte Cederlund, a non-Sámi writer. Despite their different origins, the series are more similar than different in their portrayal of most aspects of Sámi-Swedish relations. The discussion of cultural appropriations in the production and marketing of the series is contextualized within broader concerns, especially in relation to Sámi and Arctic pedagogies. We begin by noting that both protagonists are initially marginalized in both the Swedish and the Sámi contexts, but their ways of gaining agency are markedly different. Connecting these points to the authors' ethnic affiliation does not produce useful knowledge or knowledge that can be shared, two hallmarks of Sámi and Arctic pedagogies. We argue that Sámi and Arctic pedagogies provide more relevant tools for discussing cultural appropriation in relation to literature from the region than the currently dominant models derived from Anglophone contexts. Through our pedagogically inspired analyses of voice and agency in the two series, we endeavour to create a Nordic ethics of appropriation.
\end{abstract}

Keywords Swedish YA novels · Sámi · Cultural appropriation · Sámi pedagogy · Arctic pedagogy

\section{Introduction}

In a recent interview, Swedish-Sámi author Ann-Helén Laestadius was asked whether only Sámi writers may write about Sámi people. Laestadius affirmed: "Yes. There is always a risk of misrepresentation. Today, we can tell our own stories"

Handling EIC name: Victoria de Rijke.

Lena Manderstedt

Lena.Manderstedt@1tu.se

1 Luleå University of Technology, Luleå, Sweden 
(Lindström 2018). The Sámi (the indigenous people of Sweden) form one of Sweden's five national minorities. However, as with many other indigenous peoples, educational and other colonial practices mean that children of Sámi origin sometimes grew up knowing little or none of the Sámi languages. Historically, Sámi children were exposed to widespread linguistic oppression in schools in Sweden from the 1920s. A result of the language policy was that many parents did not use their language with their children. Consequently, "telling our own stories" is complicated by the fact that these stories may be told in the language of the colonizer. Viewed more positively, writing in colonial languages allows those belonging to the majority culture and other minority cultures to gain insights into the situation of the Sami peoples: a necessary step towards respecting human rights and community values. One of the key risks in such endeavours is that a minority writer like Laestadius may be essentialized, and her characters interpreted as stereotypes of "a true Sámi”, especially by readers whose capacity for nuance is still developing.

In this paper, we read Laestadius' Soppero quartet alongside the Idijärvi [Lake Idi] fantasy trilogy by Charlotte Cederlund, paying particular attention to cultural appropriation. Both series have young female protagonists whose mothers are North Sámi and fathers who are Swedish, and the plots centre on the protagonists' psychological growth in relation to their bi-cultural identity. Both girls have been raised as monolingual Swedes, and cannot communicate in Sámi. Both series were written in Swedish, both authors' native language, although Laestadius is Sámi and Cederlund is not. On the surface level, cultural appropriation is fairly straightforward. Erich Hatala Matthes defines the most important aspects as: "1) the representation of cultural practices or experiences by cultural 'outsiders' (...), 2) the use of artistic styles distinctive of cultural groups by non-members" (2016, p. 343). Cultural appropriation may also include misrepresentation, misuse, and the theft of stories and styles of "people who have been historically dominated and remain socially marginalized" (ibid.). In this light, Cederlund's trilogy is an act of cultural appropriation. An alternative explanation would be to regard the novels as an attempt to understand the Sámi perspective. Please take a moment before dismissing this provocative idea. Writing for children and/or about children's experiences-as all authors and critics of children's literature do_-also ticks Matthes' boxes for defining cultural appropriation.

In his manifesto for anti-racist children's literature, Philip Nel (2017, pp. 202-24) lists 19 actions that are primarily for Whites because "the major beneficiaries of White supremacy (...) have the strongest moral obligation to end it" (p. 202). Although both the Sámi and the majority population are White, shaming practices led many parents to refrain from speaking Sámi with their children, with the result that, even today, many people do not know their own ethnic heritage. Returning to $\mathrm{Nel}$, we agree that readers have responsibilities in relation to acknowledging the damage of colonialization (some Sami consider the era of colonization on-going), but argue that the practices need to fit the specific context and that models developed in the Anglophone world are often a poor fit for Nordic contexts. Elsewhere, in relation to poetry for adults, Kokkola and Siltanen developed Nel's (2017, pp. 67-106) calls for readings that acknowledge the interplay of race and affect as well as the "mixed bloodlines" (p. 57) of cultural influence into practices of reading 
"uncomfortably" (Kokkola and Siltanen, 2019). Uncomfortable readings recognize readers' own complicity and privilege, incorporating them into the response. Such readings may fail, but as Judith Halberstam explains: "Under certain circumstances failing, losing, forgetting, unmaking, undoing, unbecoming, not knowing may in fact offer more creative, more cooperative, more surprising ways of being in the world" (2011, pp. 2-3). Failure, in this view, is a form of norm critique that questions the measures used to define success, forming roads to other, surprising places. Rather than seeking reconciliation, recovery and knowledge, failure allows readers to remain awkward, ignorant and uncertain: in short, humble. Nel asks Whites to listen and he also points out that empathizing is not enough (2017). Following his lead, we have tried to work meta-criticism of our understanding into our analyses of the texts and invite criticism which identifies where our biases might have led us astray.

By reading the two series uncomfortably, our goal is to tease out what it means to avoid cultural appropriation whilst engaging in a dialogue using Sámi and Arctic pedagogies as a way to structure our argument. The dominant Anglophone theorisations of race and ethnicity fit poorly in the Nordic context, not least due to the assumption that racial difference is visible. We begin by providing a general overview of the historical situation of the Sámi within Sweden, and their representation in literature. We then introduce the two series, highlighting connections between the authors and their protagonists evident or missing in the marketing materials surrounding their production. Noting that any individual author must - to some extent-appropriate other cultures, genders, ages and positions in order to produce rounded characters, we highlight the pedagogical problems at stake. In conclusion, we suggest that a Nordic ethics of appropriation built of Sámi and Arctic pedagogies might offer a route forward.

\section{Contextualising the Sámi in Swedish Sápmi and in Regional Literature}

The Sámi's traditional homeland, Sápmi (still frequently referred to by its colonial name "Lapland") stretches across northern Norway, Sweden, Finland and European Russia. Within Swedish Sápmi, the 1928:43 Bill Concerning the Rights of Swedish Lapps to Reindeer Herding differentiated between Sámi people who were nomadic reindeer herders, and those who were not, according certain privileges to the reindeer herders:

However, insomuch as the Lapps, due to circumstances, have departed from the occupation of their forefathers and seek to earn their livelihood in the same way as the resident population (...), the state's reasons for upholding their legal right to the special privileges are forfeited (Proposition, 1928:43, p. 55, our translation)

Those Sámi who earned their living by other means thereby lost their privileges. This past is evident in both Laestadius' and Cederlund's series, although both are written and set in the contemporary era when Swedish law prohibits officials from 
keeping personal data concerning individuals' ethnic origins (SFS 1992:1433, Sect. 2). The only data that can be kept is self-affiliation when, for instance, an individual requests services in a minority language. Acknowledging the inhumane language policies of the past, the National Minorities Act (SFS 2009:724) grants the right to receive education in Sámi to children for whom it is a heritage language ${ }^{1}$ (see also Pietikäinen, 2008, p. 25).

Whilst self-identification is the only legal definition of Sámi ethnicity allowed in Sweden, the issue is still not clear-cut. The official website of the Sámi Information Centre (which is part of the Sámi Parliament) states:

It is partly a matter of your origin, your up-bringing, and your own choice. If you have Sami ancestors but you don't consider yourself a Sami-then you are not a Sami. On the other hand you can also have double identities: You can be both Sami and Swedish and move between the different cultural contexts. (samer.se)

Language is obviously central in individuals' experiences of ethnic belonging. In the 1970s, an ethnic and linguistic revival movement impacted on children's literature in Sámi (Hirvonen, 2014). However, few children's books are translated from Sámi into Swedish.

Sámi themes have been recognized within Swedish literature since the $17^{\text {th }}$ century. Classics include Zacharias Topelius' Sampo Lappelill: En saga från Lappland [Sampo Lappelill: A Tale from Finnish Lapland] in the third volume of the collection Läsning för barn, published between 1865 and1896, or Selma Lagerlöf's Nils Holgerssons underbara resa genom Sverige (1907) (The Wonderful Adventures of Nils). There are also stories set in the north of Sweden, with or without Sámi characters, such as Helen och lappflickan (Brattström, 1950) [Helen and the Lapp Girl] or Skatten i Nåjdsjön: två pojkars äventyr i svenska vildmarker (Westerlund, 1930) [The Treasure in the Shaman Lake: Two Boys' Adventures in the Swedish Wilderness]. None of these books was written in Sámi or by writers of Sámi origin. In a bibliography of Swedish children's and YA literature, Gerda Helena Lindskog identified 135 books published 1899-1995 containing Sámi characters, of which only 22 appeared after 1970. Moreover, Lindskog's overview reveals a strong tendency to exoticize the Sámi and their cultures, and to place them in supporting roles. Both Lindskog (2005) and Regine Nordström (2004) have identified just three Swedish books on Sámi themes for children or young adults from the 1990s. This lack of representation in contemporary literature for young readers is problematic, as it does not create spaces where majority and minority readers can engage with Sámi characters and culture. In short, Sámi voices are generally silent in Swedish youth fiction. In this context, the appearance of two series-seven novels-featuring Sámi-Swedish protagonists in the period 2007-18 stands out. Both series were written in Swedish, although they both contain some Sámi words and phrases. Sámi themes are not limited to literature for young readers. The translation of Walt Disney's Frozen 2

\footnotetext{
${ }^{1}$ Children belonging to minorities other than the five national minorities are only entitled to home language support if at least one of their parents speaks the language.
} 
into North Sámi has been greeted with great excitement in the Sámi newspapers, social media and among teacher educators. A team of Sámi representatives were asked to be consultants in order "for the Sami to receive proper representation in the movie" (Nikel, 2019).

\section{The Soppero Quartet (Laestadius) and The Idijärvi Trilogy (Cederlund)}

Laestadius' Soppero quartet debuted with SMS från Soppero [Text Messages from Soppero] (2008), two years before the National Minorities Act. The novel won a writing competition arranged by Nordiska Museet, Samiskt informationscentrum and Podium/Författarcentrum Öst [The Nordic Museum, the Sámi Information Center and Podium/Writers' Centre East] (Corneliuson, 2008). The theme of the competition was "being a young Sámi in contemporary society", and Podium/Writers' Centre East first published the novel. This Centre covers the Swedish capital, Stockholm, and other regions not traditionally associated with the Sámi. The novel SMS från Soppero was translated into three Sámi varieties: North Sámi, South Sámi and Lule Sámi, also published by Podium. The later novels in the series-Hej vacker [Hey Beautiful] (2011), Ingen annan är som du [No One Like You] (2011) and Hitta hem [Finding Home] (2012)—were, however, published by Rabén \& Sjögren. The protagonist, Agnes, is a 13-year-old from Stockholm, whose Sámi mother is from Soppero in Swedish Sápmi. Agnes falls in love with Henrik, a Sámi boy from Soppero, but struggles with the Sámi language, because her mother did not speak it to her as a child despite her passion for promoting Sámi culture. Throughout the series, Agnes loves Sámi culture, but is frustrated that her inability to speak Sámi has left her with only partial access to the culture. The novel is a Young Adult romance, but cultural identity is an important aspect of the series.

The first novel in the Idijärvi trilogy, Middagsmörker [The Darkness of the Day], written by Cederlund (2016), was published by Opal förlag, a well-established, Stockholm-based company "focused on quality literature for children and young people" (opal.se/om oss; our translation). It was followed by Gryningsstjärna [The Morning Star] (2017) and Midnattsljus [The Midnight Light] (2018). In an online interview promoting her books, Cederlund states that she has always been attracted to the unfamiliar, but her decision to set her books in Lapland (she uses the colonial term) was happenstance (bokkoll.se). She clarifies that she "knew nothing" about the Sámi when she began writing, but conducted "research" to make her stories realistic (bokkoll.se). Cederlund's own website describes the novels as being set "tucked away in the northern forests, far from civilization" (cederlund.se: our translation). Not only does this expression locate "civilization" as something separate from Sápmi-implying a colonial mindset-it is also an inaccurate portrayal of the region, as the region that inspired the novel is above the treeline. Cederlund's Idijärvi novels feature Áili, a girl in her late teens who grew up in the south of Sweden. Motherless since birth, Áili has to move to live with her maternal grandfather in Idijärvi, after her father's death. She encounters Swedish prejudices against the Sámi, and prejudice from the Sámi who question her right to consider herself Sámi. All three novels problematize Sámi identity and Sámi mysticism. The trilogy depicts 
the struggle between good and evil where Áili has a clear hero function. Thus, Áili is portrayed as both an insider, due to her mystical powers, and as an outsider who lacks knowledge of the language and culture.

Both Agnes and Áili have grown up in southern, urban settings and experience alienation in Sápmi when struggling to share these experiences with their peers, not least because they are unable to speak Sámi. Voice, agency and cultural identity are thematized in both series, but one series is written by a writer of Sámi origin, the other by a non-Sámi. None of the novels are available in English, and all translations into English are our own.

\section{Appropriated Voices: The Need for Socio-historically Situated Theories of Appropriation}

Both the Soppero quartet and the Idijärvi trilogy incorporate information concerning the historical educational practice of preventing Sámi children from speaking their own languages. This is important in books written in Swedish because, although knowledge of these practices is common among the Sami and other affected groups, many children from majority culture homes are unaware of this history. In Laestadius' novels, this history, including the punishments such as beatings and withholding food, is recalled ( $S M S$, p. 17), along with the consequences that children came to feel that Sámi was "something to be ashamed of", and so many never learned to read and write in their own language (Ingen, p. 43). Consequently, many people had "lost their language and were, in fact, like Agnes, Sámi without language" (Ingen, p. 33). The loss of language is also depicted as a loss of voice. Agnes reflects on how, when she is at home with her Swedish friends in Stockholm, she feels proud of her Sámi origin, but how obvious it is in Sápmi that she does not really belong among "her" people (SMS, p. 40). Speaking Sámi is important, as are family relations and occupations. Agnes' friend Jåke muses about this: "Just imagine if we all came here, without knowing who is who, or where people come from. And if nobody had to say whether they are reindeer herders, hunters, fishermen or urban Sámi, and we just had to get to know each other as human beings" (Ingen, p. 229). In this way, Laestadius expresses the idea that there is more to Sámi identity than the language (cf. Matthes, 2016), and identifies the loss of the Sámi languages and associated feelings of shame as being part of the Sámi’s heritage.

Ebony Elizabeth Thomas (2019) argues that representation is particularly problematic in speculative genres, although she prefers to call them the fantastic. Marginalized fictive characters are often stereotypes who function as representatives of their group. Thomas proposes the term the dark fantastic "for the role that racial difference plays in our fantastically storied imaginations" (p. 7). In the Idijärvi trilogy, magic is connected with the Sámi side of the protagonist, whereas the only speculative, or fantastic, elements in the Soppero quartet are a few spiritual incidents, such as the sighting of a Siberian jay which tells Agnes' mother that a particular site is inauspicious (Hitta, p. 185). Agnes is not portrayed as a shaman, but there is a physical affinity between the protagonist and a seite, a site of power, in this case a rock (Hitta, p. 303-304). In the Soppero quartet, magic is not a prominent theme, 
but mysticism is exclusively related to the Sámi, thereby forming an ethnic marker akin to Thomas's dark fantastic. Moreover, this affinity connects both protagonists with Sámi culture, despite their limited access to the language and traditions. The main difference lies within the degree of marginalization of the protagonist. While Agnes might feel marginalized, her family can voice and represent what it means to be a Sámi. The protagonist of the Idijärvi trilogy, on the other hand, is marginalized by both her lack of cultural capital in the Sámi context and her lack of family support. By turning the protagonist into a shaman, however, Cederlund's novels attempt to make Áili represent the Sámi. The story builds on the idea of ethnic and cultural differences, although both the Sámi and Swedes are Whites.

Both protagonists were raised in Swedish-dominant environments: Agnes due to her mother's ambivalent attitudes towards her ethnicity, and Áili due to the death of her mother. Their lack of proficiency in Sámi makes it harder for them to claim their birth-right. Both protagonists reflect on how their capacity to make themselves heard is context-specific. Their agency as girls and minors is further undermined by their lack of voice. Agnes comes to understand that "Sámi was a given ticket in" (Ingen, p. 205). When Áili meets the president of the Sámi village, and he realizes that she cannot speak Sámi, he states that "the language is part of our cultural heritage, part of what makes us Sámi", and he questions whether she can call herself Sámi if she does not speak the language (Middagsmörker, p. 24). Throughout both series, speaking a Sámi language is synonymous with voicing ethno-cultural experience and identity.

Whilst we do not wish to conflate the protagonists' identities and knowledge of Sámi culture and languages with those of their creators, the issue of cultural appropriation demands that we consider how the author's ethnic identity is evident in the respective series and in the marketing material that surrounds their circulation. Jenny R. Lawy explains that "voice is not only about speaking, participating or making yourself heard", critics must also acknowledge that voice "relies upon dominant structures to legitimize it" (2017, p. 192). The decision of the Sámi Information Centre to commission (through the writing competition), translate and circulate Laestadius' books provides a seal of approval from within the Sámi community. The adoption of the later books by one of Sweden's best-known publishers for youth indicates a broader acknowledgment of marketable quality. Cederlund's books are published by an independent, well-known publisher, but have not been translated into Sámi. Limited funding for translations is available from both governmental and private foundations, so the lack of translation indicates a lack of interest from within the Sámi community to see the Idijärvi series become part of the Sámi canon. Moreover, Laestadius' novels appear on some curricula in Sweden, Norway and Finland, but Cederlund's do not.

Both series problematize the place of the Sámi language in identity construction, simultaneously resonating with the dominant structures in society that left the protagonists' forebears feeling ashamed of their language and acknowledging the right to determine who belongs. In doing so, both contribute to the image of the Sámi as a monoculture. This idea is expressed by one of Laestadius' teenage characters: "Without the reindeer, nature and language, it was just not possible to be a Sámi" (SMS, p. 17). Agnes internalizes this message: "she was still a little outside. The lost 
language had also created the small but difficult distance to the others. A true Sámi can speak Sámi” (Hej, p. 86). Agnes tries to find complementary ways to express her Sámi identity whilst studying the language. For example, she walks through the village dressed in her Sámi dress to show who she is (Hej, p. 236). Laestadius' interview comment that, at the age of 13, she was unlike Agnes, and wanted to hide her Sámi identity; Sámi was also a "lost language" for the author. In the same interview (and in the photo accompanying it), Laestadius describes the pride with which she wears her Sámi dress today (Författarcentrum). In short, Laestadius's books are marketed by drawing parallels between her lived experiences and those of her character. These statements position Laestadius as having the authority to voice the experiences of Sámi youth in contemporary Sweden.

At the outset, Cederlund's character, Áili, speaks no Sámi. Her Sámi mother died whilst giving birth, providing an explanation as to why she speaks only Swedish. In this way, the series dodges the emotional complexity of shame which underlies the failure to pass on the language from one generation to the next. Nevertheless, Cederlund incorporates a scene where Áili experiences some of the shaming of the Sámi when a non-Sámi person hurls the insult 'lappjävel' ${ }^{2}$ at her (p. 58), enabling readers to experience its impact. Áili is "surprised how it hurts, how deep the word burrows into her chest. It is a word that diminishes, which cuts where it hurts most" (Gryningsstjärna, p. 58). The scene establishes the tensions between the Sámi and the non-Sámi, but Cederlund focuses on depicting Áili's difficulties in finding acceptance among the Sámi. For instance, the president of the Sámi village positions her as Swedish without access to and knowledge of what it is to be a Sámi:

- You don't fit in here. You have no idea how it is to be a Sámi, what it is like to live every day in resistance. Resistance to our lifestyle, our tradition, the right to our culture. You think you are a Sámi by blood, that your moving here makes you as Sámi as me. It's not like that. You're not a Sámi, you're nothing. His words are like a fist in the stomach. I have never felt like a Sámi, my Sámi heritage has always been a part of myself that I have not been able to access. Until now. I may not know what it is like to live like a Sámi but I have never felt as much Sámi as I do now.

(Middagsmörker, 239, our italics)

Áili tries to "access" her Sámi identity, or rather, her dual identity, by protesting: "I am certainly a Sámi" but she is reprimanded: "You are no more Sámi than the idiots in Kiruna" [a northern Swedish city, known for the mining company which built the town] (Middagsmörker, p. 239). Thus, Áili is rendered both voiceless and marginalized, accepted by no one.

Áili's experiences reflect those of many Sámi-by-blood in real life, and in an interview Cederlund claims that many of the examples of racism directed at Sámi people were taken from newspapers (Bokkoll.se). However, by focusing on rejection from within the minority (rather than majority oppression), Cederlund's appropriation

\footnotetext{
${ }^{2}$ The term literally means 'Lapp-devil'; it has the same strength and level of offensiveness as the $\mathrm{N}$ word for African Americans.
} 
of Sámi culture becomes problematic as the Sámi community is blamed more than the Swedish community. On the other hand, when the Sámi writer makes Sámi people reject her protagonist, Laestadius is not accused of cultural appropriation. In terms of plot and character, Cederlund's and Laestadius' series are similar, so criticizing Cederlund and praising Laestadius cannot be justified. Both series assert essentialism: their characters are Sámi partly on the basis of blood ties, but mainly on the basis of the individual's cultural capital. The use of Laestadius' life-story to promote the series can be understood as "strategic essentialism", the controversial term expounded by Gayatri Spivak (1996) to describe the way disempowered people may emphasize their ethnic heritage to further their emancipatory efforts. Strategic essentialism, as Noble, Poynting and Tabar define it, is "the articulation of an irreducible otherness which is operationalised primarily for the critical speaking position it offers minority intellectuals" (1999, p. 31). Thus, when Laestadius draws parallels between her life and that of her protagonist, she can be understood to be engaging in the kind of strategic moves Spivak envisages, albeit without necessarily knowing anything about Spivak's ideas. Strategic essentialism has been critiqued in the academy, primarily because it implies that an "essence" exists, but holds traction when describing the packaging of authenticity for political purposes. Cederlund tries to deploy something similar when encouraging her readers to side with Áili and view her blood ties as an "essence" of identity, but this cannot be dubbed strategic essentialism as Cederlund has no ties to either the people or the region. "Strategic essentialism" is problematic, but it touches the raw nerve at the centre of debates on appropriation.

Creating fictional characters always involves what Matthes labels "voice appropriation" (p. 343). Authors must imagine themselves into the thoughts, feelings, beliefs and body of the character in order to create any depth. Thus, novelists can use their powers of imagination and empathy to create characters from ethnic backgrounds other than their own. Accepting this is not, however, the same as hoping that "the concept of cultural appropriation is a passing fad" as Lionel Shriver did in her keynote address to the Brisbane writers' festival in 2016. Shriver (2016) pointed out how limited and non-representative of society fictional worlds would be if authors could only write from within their in-group. Reporters like Stephanie Convery (2016) interviewed authors at the festival who were saddened that opportunities for a genuine discussion had been damaged by the vitriolic positioning of “them" against "us". Karen Coats' (2017) discussion of conflicts surrounding diversity in youth literature highlights the increasing partisanship of debates surrounding the representation of race and ethnicity in the American context. The quantity of theorizing that stems from the Anglophone, especially American, contexts gives the impression that such partisanship is normal. But these models do not fit well with the Nordic mindset.

As evidence that "a Nordic mindset" exists and has value, let us briefly compare the election systems in the U.S. with those of Sweden. In the U.S., there are two major parties, and the House of Representatives and the Senate are led by a single party and opposed by the other party. In contrast, in Sweden (like Norway and Finland) there are many political parties and governments are always formed as coalitions. The main parties recognize the need to work together to achieve common 
goals, and so consensus politics and dialogue prevail. We propose that the partisan nature of the political system is causing analogous tensions in discussions of diversity in the U.S., whereas the Nordic countries will approach questions of ethnicity based on the dialogue. Coats (2017) describes the vitriolic response to Marisol, a novel by the Chicano author, Gary Soto (2004). This story of a Mexican-American girl moving to Des Moines was criticized because the parents' desire to leave Chicago was based on their concerns about their daughter's quality of life in the largely Hispanic urban area. The debate became so heated, Soto decided to stop writing children's books altogether. A similar debate concerning the smiling face of a slave in A Birthday Cake for George Washington (2016), written by Ramin Ganeshram and illustrated by Vanessa Brantley-Newton, led the publisher, Scholastic, to withdraw the book even though the author, illustrator and editor were all women of colour (see also Thomas et al., 2016). These events indicate that, within the U.S., the ethnicity of the producers is an insufficient measure for diversity. But as Coats notes, limiting the scripts of acceptable stories runs counter to the spirit of promoting diversity. If authors like Soto fall silent, even fewer will attempt to portray the lives of children from minority backgrounds. If, in the Swedish context, only stories of Sámi who live in Sápmi, speak one of the Sámi languages and own reindeer are acceptable, the lived experiences of many Sámi today will be ignored. The only people who would benefit from such a narrowing of the field are those who either wish to exoticize the Sámi and/or those who wish to see them ignored.

A literature for youth that reflects the diversity of experiences of those reading them also provides a potential for out-group members to gain insight into in-group experiences, thoughts and beliefs. Our example series are similar in terms of the way they depict Sámi motifs and the voices of the protagonists. In terms of plot complexity, the roundedness of the characters or attitudes towards Sámi-Swede relationships, they are more similar than different. Nevertheless, we earlier asserted our opinion that it was "problematic" that Cederlund chose to focus on the Sámi people's rejection of Áili rather than on the majority culture's role in causing feelings of selfalienation simply because Cederlund is not Sámi herself. And yet we judged Laestadius' text, which incorporates the same dynamic, to be realistic. Did you notice this? Does it matter that one of us has Sámi ancestry? Does it affect your interpretation of our argument to learn that the other two also belong to other national minority groups? Do we have the right to speak for our respective groups? Posing direct questions in the midst of an academic discussion and admitting that one does not have all the answers is a common feature of Nordic writing. Perhaps it made you feel 'uncomfortable'? We hope so, as feeling uncomfortable is, as Nel noted, an important part of changing. Asking questions rather than trying to form judgments strikes us as a more productive route to forming an ethics of voice appropriation that can take us beyond empathy. Moreover, this approach aligns well with Arctic and Sámi pedagogies.

In their overview of Sámi pedagogies, Outi Laiti and Satu-Maarit Frangou identify "three essential conceptions: time, place, and knowledge. The Sámi see time as sun-centered and bound to nature. Additionally, Sámi education is not bound to any building or classroom (...). Finally, knowledge that is passed on needs to be useful in practice and readily shared with others. Knowledge, according to this pedagogy, 
results from negotiations and discussions" (2019, p. 8; see also Keskitalo, Uusiautti and Määttä, 2012). The latter point is further expanded in their discussion of Arctic pedagogies which highlight the social skills of imitation, shared attention, and empathy. Literature, with its potential for developing such social skills as well as resonating to the time, place and knowledge concerns of the Sámi easily forms part of Arctic and Sámi pedagogical practice. Regarding imitation as a social skill has interesting implications for thinking about voice appropriation. Can works like Cederlund's novels be considered a negotiation, a discussion, a way to form practical knowledge? After all, adult authors of youth fiction appropriate the voices of children and adolescents. So, rather than dismissing appropriation outright, Rosemary J. Coombe argues for "an ethics of appropriation" (1993, p. 270) on the grounds that prohibiting acts of cultural appropriation is impossible. Coombe's "ethics of appropriation" can be questioned on similar grounds to Spivak's "strategic essentialism", but produces practical knowledge and knowledge sharing practices favoured by Sámi pedagogies. Ethically sound ways of writing and marketing books with minority protagonists that do not undermine the emancipatory efforts of disadvantaged groups need to be found. Questions need to be asked, and although we cannot answer all the questions ourselves, we hope that they start a pedagogically sound debate that fits the Nordic context.

\section{Agency in a Nordic Ethics of Appropriation}

Discussions of appropriation tend to highlight ownership of culture, which implies that some authors have the right to speak for an entire group: a view which leads to the unhelpful conflicts Coats identified. By appropriating the voices of teenaged Swedish Sámi girls, Laestadius and Cederlund leverage agency for their protagonists. We suggest that if voice appropriation models the actions needed to become powerful, the potential for providing the forms of practical knowledge required by Sámi pedagogies, and conceivably form part of an ethics of appropriation becomes possible. In what follows, we consider how Agnes' and Áili's access to Sámi society is initially limited by gatekeepers, although later in the series they take on the roles of guardians of their people. We then consider the extent to which this might help form practical knowledge for generating an ethics of appropriation.

Our understanding of appropriation is informed by Sara Ahmed's Queer Phenomenology (2006) in which she notes that the expression "sexual orientation" contains the idea that desire is, at least partly, a form of movement, of finding one's way. Given the connection of the Sámi to Sápmi, and especially the spatial characteristics of traditional practices such as herding, hunting and fishing which require an intimate knowledge of the land, flora and fauna, understanding Sámi ethnicity as a way of orientating oneself, of finding one's way within Sápmi provides useful tools for investigating agency. In both series, Sámi identity is closely aligned with the characters' relationships with the landscape of Sápmi: the characters need to orientate themselves towards the landscape in order to be recognized as Sámi. Agnes is told by her boyfriend's mother that Henrik is to be a reindeer herder and must stay in 
Soppero, whereas Agnes must find her way in Stockholm (Hej, pp. 157-158). Her ethnic bloodlines do not automatically translate into "belonging to" Sápmi: she must learn to navigate like those who grew up in the region earning their living from the land.

Ahmed's expansion of the notion of orientation sits well with Michel de Certeau's notion of spatial practice (1984): the way in which people's use of urban spaces frequently differs from the officially sanctioned expectations inscribed on maps. De Certeau notes how people on the street "make use of spaces that cannot be seen" (p. 93), for instance, by choosing routes based on habits or desires, not on efficiency. For de Certeau, such spatial practices are forms of resistance. Sámi movements across spaces designated as "wilderness" could be regarded as de facto forms of resistant spatial practice. Western maps of Sápmi highlight roads and permanent dwellings. Most of the national borders within Sápmi are formed by rivers, implying that rivers are barriers. Whereas, Sámi movements have traditionally been based on the movements of animals. Rivers are passages through the landscape rather than barriers (the local name of the Torne river marking the Swedish-Finnish border on Western maps indicates the river's power to connect people, not separate them). These contrasting ways of moving and understanding the landscape have indeed contributed to distinctions between Sámi and Swedish cultures. For the characters in the novels, entry into the Sámi community requires the ability to navigate the physical environs of Sápmi in the way that their blood relatives have done for centuries.

Michel Foucault (1986) draws on de Certeau's notion of spatial practice to create the term heterotopia which refers to non-public spaces, secret spaces where "to get in, one must have certain permission and make certain gestures" (p. 26). Although Foucault is discussing entry into specifically queer spaces (such as bars and clubs), the negotiations undertaken by the female protagonists wanting to enter the Sámi community closely resemble the "policing" of the borders Foucault describes. For the most part, the gatekeeping practices are initiated by male members who unequivocally belong to the Sámi community (they know the language, the customs and the land), although there are also female characters who function as gatekeepers in both series. Áili's encounter with the head of the village cited above is the most obvious example of gatekeeping, since he explicitly tells her that she is "not Sámi", but Agnes feels equally excluded when the Sámi youth at a confirmation camp break off into groups to speak their home languages: "Agnes listened and longed" (Ingen, p. 166). Accepting that the gesture she must make (in the Foucauldian sense) to enter the community is to learn davvisámegiella (North Sámi), Agnes studies hard, and seeks other ways in which she can use to signal her desire to be Sámi, such as her clothing.

The protagonists' lack of linguistic proficiency does not render interaction with the fictional Sámi context impossible, as everyone speaks Swedish. The potential for knowing one another is always open. Whilst gatekeeping is most easily understood in terms of encounters between the protagonists and Sámi gatekeepers, we would also like to expand the original spatial characteristics of gatekeeping by considering the characters' capacities to enter Sápmi. In a study of the Canadian Mennonite author, Rudy Wiebe, Janne Korkka problematizes not only the capacity of humans to know one another, but also human capacities for knowing the land. His 
argument, grounded in the work of Emmanuel Levinas, is that whilst human relations are always grounded in reciprocity, relationships with space and land may not be. That is, attempts to communicate with another person (or, indeed, attempts to understand oneself) are grounded on a willingness to change. Over-simplified, this means that the willingness of the protagonists to be changed by their encounters with the Sámi provides a means for them to know and be known. However, there may be limits, and recognizing that the land has agency may also be relevant in relation to indigeneity.

In the novels, animals, plants, the physical landscape and the climate all form parts of the unknowable other. The Sámi's relationship with reindeer also functions as a gatekeeping device in these novels. Despite her urban childhood, Áili is exceptionally good at handling reindeer. The animals intuitively respond to her, coming close when she stretches out her hand and indicating that they would like to be stroked. Válde, a young Sámi, reminds her that reindeer are not pets (Middagsmörker, pp. 65-66), but nobody can deny that the reindeer choose Áili. Consequently, the Sámi feel that they must respect her as well, thereby according her greater agency. The implication is that the animals recognize that Áili is a true Sámi more easily than some humans.

Áili's relationship with the reindeer is unrealistic, but not as obviously fictional as her means of entering the Sámi community via a fantastic relationship with Sápmi. Áili enters the spirit world by connecting with her spirit animal, a wolf. Once there, she literally becomes part of Sápmi: "I am part of this world, part of the people who populate it and part of its nature. I am a part of Sápmi and in it lies my power. A power that no one will be able to take away from me, ever" (Midnattsljus, p. 285). In the spirit world, Áili encounters the spirit of her mother, who reveals that Áili is destined to become a guardian of "her" people. Middagsmörker, p. 77). Please note the possessive qualities of the word "her": it implies that Áili "owns" the Sámi. Throughout the series, Áili battles evil shamans and tricksters who threaten the Sámi. Áili straddles the worlds of Swedes and Sámi, and she also becomes a bridge between the lived world and the world of the spirits. As a noaidi (shaman), she has considerable agency, not least because she acts as a gatekeeper preventing the bad spirits from entering the daily lives of the seemingly powerless Sámi. The mythology draws on colonial interpretations of Sámi practices: Lotta Olsson (2016) shows how Cederlund's series sets aside Celtic myths which have "functioned as the common property of fantasy literature" (our translation), to highlight pseudo-Sámi mythologies.

Áili's route to agency is not primarily gained by undertaking the hard work of learning the language, culture and land. Instead, magic is used to place her in power over the Sámi. In our aforementioned article, we outlined the "hard work" that is needed for out-group members to read Sámi literature respectfully (Kokkola and Siltanen, 2019). The concept of "hard work" is important, according to one of the Sámi reviewers of that paper, and "the point is that you need to do what it takes to acquire the necessary knowledge to do the work. Since knowledge about the Sámi society and people is not 'common knowledge' for most people, it requires even more hard work to analyze Sámi cultural expressions". Traditionally, the noaidi served as guides and mediators rather than the leader-warrior 
role after a long period of training involving physical, mental and spiritual hardships. Historically, their importance to the Sámi was recognized by those in power through death sentences, the removal of drums connected to shamanistic rites (Hagen, 2006). Sites of power were desecrated, often by being turned into tourist destinations. Áili requires no training and her transformation can be dismissed using a model of appropriation that highlights the fact that Cederlund is not Sámi. Cederlund claims to have conducted "research", but as we have already noted, she makes basic errors about the region, the people and cultural practices. But if we want to develop an ethics of appropriation that suits the Nordic context, these observations do no work. They tie us to Anglophone notions of cultural ownership and do not produce the practical knowledge a Sámi or Arctic pedagogy requires.

A workable model that provides the practical knowledge needed demands hard work and should be based on reciprocity. However, the long history of abuse means that those who have received noaidi training do not share the details of their practices. Sharing knowledge is an important aspect of Arctic pedagogy, but there are limits, perhaps most easily defined by their practical use. Knowledge of noaidi training may be interesting to an outsider, but is of no practical use to those who are not destined to become noaidi themselves. And whilst we would not go so far as to claim that literature depicting such training is impossible, sharing such rituals seems antithetical to the spirit of shamanism as practised among the Sámi. In short, an ethics of appropriation founded on the requirements that it produce practical knowledge that can be shared allows us to criticize Cederlund's novels, not because she is not Sámi, but because her representation of shamanic practices is neither practical, nor should such knowledge be shared.

The novels do produce practical knowledge of the experiences of feeling caught between two cultures, and the steps taken by the protagonists to gain agency within the Sámi community. Both Agnes and Áili try to put in the hard work needed to learn the language, but their progress is limited. Agnes' decision to explore her Sámi identity positively impacts on family problems, even though her father is initially sceptical about her "Sámi project" (Hej, p.15). Her mother begins to reconcile herself with her past, as she reconnects with friends and wants to build a house in Sápmi. Agnes' desire to learn davvisámegiella encourages her mother to use it with Agnes' baby brother (Ingen, p. 130). When Agnes appears in a Sámi dress at her grandmother's birthday party, her mother feels excluded as the only person at the party dressed in modern clothes. Agnes' actions cause her mother to decide that promoting Sámi issues in the Swedish media is not enough; she wants to rekindle a closer connection to her birth culture, language and people. Agnes also brings an outsider's perspective to bear on the Sámi characters' self-perception as a group. For example, she questions the notion that Sámi people are sexually homogenous (Hitta, p. 216), makes her peers question the prejudices against Sámi people who are not into reindeer husbandry (Ingen, p. 165) and gender prejudices against female reindeer herders (SMS, p. 15). In short, Agnes gains agency through her willingness to "reconstitute" herself in the face of the other and through others' willingness to be reconstituted in return (cf. Korkka 2013, p. 9). In terms of an ethics of appropriation, Agnes' hard work 
and willingness to be changed produces practical knowledge in dialogue with her birth family, her extended families and her bi-cultural experiences.

\section{Towards a Nordic Ethics of Cultural Appropriation in Literature}

As we hope to have shown, there are numerous similarities between Laestadius' and Cederlund's novels: a teenage protagonist, with a Sámi mother and a Swedish father, struggles with her feelings of being "part-time Sámi” (Ingen, p. 220). Initially both girls feel excluded from the community due to their lack of proficiency in davvisámegiella, thereby exposing hierarchies within Sámi communities. Conflicts between the Sámi and Swedes are a historical reality, and both series are rooted in this historical context to the extent that clear "us" and "them" divisions are normalized, even though both protagonists represent a lived reality that belies such absolute distinctions. They gain voice and agency throughout the series, but their routes to empowerment differ. In the Soppero quartet by the writer of Sámi origin, Agnes has a self-evident affiliation with her Sámi relatives, as she has spent time in Sápmi during her childhood and has functional relationships with her Sámi relatives. Neither her dual identities as Swedish and Sami, nor her linguistic deficiency disqualify her entirely, although she does feel marginalized. In the Idijärvi trilogy by the non-Sámi writer, Áili's voice and agency stem from shamanic powers, which grant her power over the Sámi rather than power to achieve self-determination (cf. Trites, 1998, p. 6). Both series are marketed using material that is intended to emphasize insider knowledge: Cederlund describes her consultations with three young Sámi who live in Kiruna, while Laestadius refers to her own childhood.

Arguing for a way to build an ethics of voice appropriation that is not based on essentializing the authors' birth-right, we suggest that the more pertinent question is not "who writes?" but rather questions such as "how do the characters model ways of being in the world?", "are their actions in accordance with the values and cultural practices of a disadvantaged group?" and, in the European Arctic at least, "does this produced practical knowledge that should be shared?" Posing such questions does not mean ignoring ethnic affiliation, but it does call for a focus on community reactions rather than individual rights to knowledge. The community responses to two series indicate a marked difference. Laestadius' quartet has been translated into several Sámi languages, but Cederlund's trilogy has not. Given the scarcity of contemporary literature depicting Sámi characters for young readers (Sametinget), the decision to translate the Soppero quartet but not the Idijärvi trilogy could easily be understood as an endorsement based on the authors' ethnic affiliations. But the decision to translate Frozen 2 and other works by non-Sámi writers indicates that this is a value judgment. Failing to endorse literary texts may seem a weak strategy, but it avoids the vitriol of "teaching conflicts" (the solution Coats offers within the U.S. context).

Sámi culture is marginalized in literature for young readers. The National Minorities Act from 2009 may have encouraged writers to take up such topics as all but one of the novels we discuss was published after 2009. Laestadius wrote in 
Swedish, and thus reached out to readers who had no Sámi background, including Cederlund, who acknowledges that Laestadius' novels about Agnes inspired the Idijärvi trilogy (cederlund.se 2018). This underscores the importance of Sámi writers taking up Sámi motifs in literature for young readers in the national languages, but also the potential risks if such readers then believe that they "know" Sámi culture as a result. The Soppero quartet models the hard work needed, but it also underscores the necessity of support. Unlike Áili, Agnes has the support of her mother's family. Áili has no one, apart from the spirit of her dead mother. Laestadius' comment that she wished she could have been more like Agnes when she was growing up, indicates that there is a real need for this kind of fiction. Reading Cederlund's trilogy as an homage to Laestadius' quartet concretizes the positive way in which the story reaches out to a broader, Swedish readership who may struggle with their own feelings of voicelessness and lack of agency. However, the exoticization of the Sámi, and especially of shamanism, in Cederlund's writing reveals the dangers of believing that one understands a culture simply by empathizing with fictional characters representing that culture. YA literature representing indigenous peoples and/or national minorities has the potential to decolonize the mind by questioning whose perspective is privileged, and by addressing questions of transculturation thereby impacting positively on lived realities. But only if there is dialogue between the communities.

Acknowledgements Open access funding provided by Lulea University of Technology.

Open Access This article is licensed under a Creative Commons Attribution 4.0 International License, which permits use, sharing, adaptation, distribution and reproduction in any medium or format, as long as you give appropriate credit to the original author(s) and the source, provide a link to the Creative Commons licence, and indicate if changes were made. The images or other third party material in this article are included in the article's Creative Commons licence, unless indicated otherwise in a credit line to the material. If material is not included in the article's Creative Commons licence and your intended use is not permitted by statutory regulation or exceeds the permitted use, you will need to obtain permission directly from the copyright holder. To view a copy of this licence, visit http://creativecommons.org/licen ses/by/4.0/.

\section{References}

Ahmed, Sara. (2006). Queer Phenomenology: Orientations, Objects, Others. Durham, NC: Duke University Press.

Bokkoll.se. (2017). Författarintervju med Charlotte Cederlund [An interview with the author Charlotte Cederlund]./Accessed November 24, 2019 from http://bokkoll.se/2017/06/23/forfattarintervju-medcharlotte-cederlund/.

Brattström, Inger. (1950). Helen och lappflickan [Helen and the Lapp Girl]. Uppsala: Lindblad.

Cederlund, Charlotte. (2016). Middagsmörker [The Darkness of the Day]. Stockholm: Opal.

Cederlund, Charlotte. (2017). Gryningsstjärna [The Morning Star]. Bromma: Opal.

Cederlund, Charlotte. (2018). Midnattsljus [The Midnight Light]. Bromma: Opal.

cederlund.se. (2018). Charlotte Cederlund. Accessed December 29, 2018 from http://www.charlottec ederlund.se.

Coats, Karen. (2017). Teaching the Conflicts: Diverse Responses to Diverse Children's Books. In Clémentine Beauvais and Maria Nikolajeva (Eds.), The Edinburgh Companion to Children's Literature (pp. 13-28). Edinburgh: Edinburgh University Press. 
Convery, Stephanie. (2016). We Need to Talk About Cultural Appropriation: Why Lionel Shrivers' Speech Touched a Nerve. Accessed September 14, 2019 from https:/www.theguardian.com/books/2016/ sep/15/we-need-to-talk-about-cultural-appropriation-why-lionel-shrivers-speech-touched-a-nerve.

Coombe, Rosemary J. (1993). The Properties of Culture and the Politics of Possessing Identity: Native Claims in the Cultural Appropriation Controversy. Journal of Law and Jurisprudence, 6(2), 249-285.

Corneliuson, Cay (2008). Sms från Soppero. Samiska funderingar prisade. [Sms from Soppero. Sámi reflections awarded]. Svenska Dagbladet.

de Certeau, Michel. (1984). The Practice of Everyday Life. Trans. Steven Rendall. Berkeley: University of California Press.

Foucault, Michel. (1986). Of Other Spaces. Trans. Jay Miskowiec. Diacritics 16(1), 22-27.

Författarcentrum. (n.d.). Ann-Helén Laestadius. Accessed June 10, 2019 from https://ff.forfattarcentru m.se/forfattare/1817/Ann_Hel_n_Laestadius.

Ganeshram, Ramin, and Brantley-Newton, Vanessa. (2016). A Birthday Cake for George Washington. New York: Scholastic.

Hagen, Rune Blix. (2006). Sami Shamanism: The Arctic Dimension. Magic, Ritual, and Witchcraft., $1(2), 227-233$.

Halberstam, Judith. (2011). The Queer Art of Failure. Durham: Duke University Press.

Hirvonen, Vuokko. (2014). Samisk barnelitteratur-mellom lokal og global kultur. Accessed April 7, 2019 from https://barnebokinstituttet.no/aktuelt/samisk-barnelitteratur-mellom-lokal-og-global-kultur/

Keskitalo, Pigga, Uusiautti, Satu, and Määttä, Kaarina. (2012). How to Make the Small Indigenous Cultures Bloom? Special Traits of Sámi Education in Finland. Current Issues in Comparative Education, 15(1), 52-63.

Korkka, Janne. (2013). Ethical Encounters: Spaces and Selves in the Writings of Rudy Wiebe. Leiden: Brill Academic Publishers.

Kokkola, Lydia and Elina Siltanen. (2019). My Hard-Earned (Sámi) Identity’: The Hard Work of Uncomfortable Reading. Scandinavian Studies.

Laestadius, Ann-Helén (2012/2007). SMS från Soppero [Text Messages from Soppero]. Stockholm: Rabén \& Sjögren.

Laestadius, Ann-Helén. (2011a). Ingen annan är som du [No One Like You]. Stockholm: Rabén \& Sjögren.

Laestadius, Ann-Helén. (2011b). Hej vacker [Hey Beautiful]. Stockholm: Rabén \& Sjögren.

Laestadius, Ann-Helén. (2012). Hitta hem [Finding Home]. Stockholm: Rabén \& Sjögren.

Lagerlöf, Selma. Nils Holgerssons underbara resa genom Sverige. Första bandet (The Wonderful Adventures of Nils. Tome 1). Albert Bonniers förlag, Stockholm 1907. Accessed November 27, 2019 from https://litteraturbanken.se/forfattare/LagerlofS/titlar/NilsHolgersson1/sida/-4/etext

Lagerlöf, Selma. Nils Holgerssons underbara resa genom Sverige. Andra bandet (The Wonderful Adventures of Nils. Tome 2). Albert Bonniers förlag, Stockholm 1907. Accessed November 27, 2019 from https://litteraturbanken.se/forfattare/LagerlofS/titlar/NilsHolgersson2/sida/-2/etext.

Laiti, Outi, and Frangou, Satu-Maarit. (2019). Social Aspects of Learning: Sámi People in the Circumpolar North. International Journal of Multicultural Education, 21(1), 5-21.

Lawy, Jenny R. (2017). Theorizing Voice: Performativity, Politics and Listening. Anthropological Theory., 17(2), 192-215.

Lindskog, Gerda Helena. (2005). Vid svenskhetens nordliga utposter: Om bilden av samerna i svensk barn- och ungdomslitteratur under 1900-talet [At the Northern-most outposts of Swedishness: The Portrayal of the Sámi in Swedish Literature for Young Readers]. Lund: BTJ förlag.

Lindström, Åsa. (2018). Den samiska litteraturen lyfter inför jubileum. [A Take Off for Sámi literature Ahead of the Commemorative Event]. Norrbottens-Kuriren.

Matthes, Erich Hatala. (2016). Cultural Appropriation Without Cultural Essentialism. Social Theory and Practice, 42(2), 343-366.

Nel, Philip. (2017). Was the Cat in the Hat Black?: The Hidden Racism of Children's Literature, and the Need for Diverse Books. Oxford: Oxford University Press.

Nikel, David (2019). Disney's Upcoming 'Frozen 2' Inspired By the Scandinavian Sami. Accessed December 20 from https://www.lifeinnorway.net/frozen-2-sami/.

Noble, Greg, Poynting, Scott, and Tabar, Paul. (1999). Youth, Ethnicity and the Mapping of Identities: Strategic Essentialism and Strategic Hybridity Among Male Arabic-speaking Youth in South-Western Sydney. Communal/plural, 7(1), 29-44. 
Nordström, Regine. (2004). De osynliga samerna [The Invisible Sámi People]. Provins. Litterärt Magasin, 24(3), 64-68.

Olsson, Lotta. (2016). Charlotte Cederlund:”Middagsmörker”. Dagens Nyheter.

opal.se. (n.d.). Om förlaget [About the Publisher]. Accessed November 24, 2019, from https://www.opal. se/om-oss.

Pietikäinen, Sari. (2008). Sami in the Media: Questions of Language Vitality and Cultural Hybridisation. Journal of Multicultural Discourses, 3(1), 22-35.

Proposition 1928:43 om de svenska lapparnes rätt till renbete i Sverige [Bill Concerning the Rights of Swedish Lapps to Reindeer Herding]. Accessed October 8, 2019 from https://weburn.kb.se/riks/ tv\%C3\%A5kammarriksdagen/pdf/web/1928/web_prop_1928_43/prop_1928_43_01.pdf

Samer.se. Who is a Sami?. Accessed April 7, 2019 from http://www.samer.se/4533.

Sametinget. Samiska barnböcker en bristvara i Sverige [Sámi Children's Books are Scarce in Sweden]. Accessed November 16, 2018 from www.sametinget.se/13455.

Shriver, Lionel. (2016). Lionel Shriver's full speech: 'I hope the concept of cultural appropriation is a passing fad'. Accessed September 23, 2019 from https://www.theguardian.com/commentisf ree/2016/sep/13/lionel-shrivers-full-speech-i-hope-the-concept-of-cultural-appropriation-is-a-passi ng-fad.

SFS 2009:724. Lag om nationella minoriteter och minoritetsspråk [The National Minorities and Minority Languages Act]. Stockholm: Kulturdepartementet.

SFS 1992:1433 Sametingslag [The Sámi Parliament Act 1992:1433]. Stockholm: Kulturdepartementet.

Soto, Gary. (2004). Marisol. Middleton, WI: American Girl Publishing Inc.

Spivak, Gayatri Chakravorty. (1996). Subaltern Studies: Deconstructing Historiography. In Donna Landry and Gerald MacLean (Eds.), The Spivak Reader (pp. 203-236). New York: Routledge.

Thomas, Ebony Elizabeth. (2019). The Dark Fantastic: Race and the Imagination from Harry Potter to the Hunger Games. New York: New York University Press.

Thomas, Ebony Elizabeth, Reese, Debbie, and Horning, Kathleen T. (2016). Much Ado About A Fine Dessert: The Cultural Politics of Representing Slavery in Children's Literature. Journal of Children's literature, 42(2), 6-17.

Topelius, Zacharias. (1930). Sampo Lappelill: En saga från Lappland [Sampo Lappelill: A Tale from the Finnish Lapland]. Stockholm: Bonnier.

Trites, Roberta S. (1998). Disturbing the Universe: Power and Repression in Adolescent Literature. Iowa City: University of Iowa Press.

Westerlund, Hans G. (1930). Skatten i Nåjdsjön: två pojkars äventyr i svenska vildmarker [The Treasure in the Shaman Lake: Two Boys' Adventures in the Swedish Wilderness]. Stockholm: Bonnier.

Publisher's Note Springer Nature remains neutral with regard to jurisdictional claims in published maps and institutional affiliations.

Lena Manderstedt is a senior lecturer in Swedish and Education at Luleå University of Technology, Sweden. Her research interests are mainly literature, literature and education in relation to the media, children, youth and online cultures and different aspects of ideology and power.

Annbritt Palo is a senior lecturer in Swedish and Education at Luleå University of Technology, Sweden. She is primarily interested in issues of literature, literature and education, gender, intersectionality, media literacy and curriculum theory.

Lydia Kokkola is a senior lecturer in English Language Learning and Teaching at the University of Oulu, Finland. Her current research focuses on reading processes in relation to fiction and online information searches. 